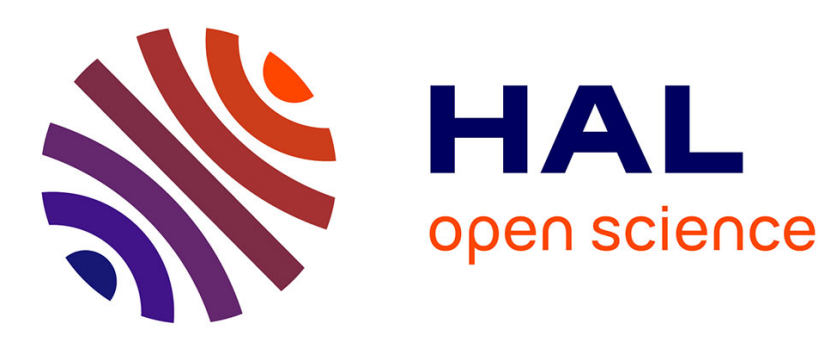

\title{
Business Collaboration - An Approach Towards End-to-End ICT Solutions for Virtual Factory
}

\author{
Ahm Shamsuzzoha, Petri Helo
}

\section{To cite this version:}

Ahm Shamsuzzoha, Petri Helo. Business Collaboration - An Approach Towards End-to-End ICT Solutions for Virtual Factory. 12th IFIP International Conference on Product Lifecycle Management (PLM), Oct 2015, Doha, Qatar. pp.738-747, 10.1007/978-3-319-33111-9_67 . hal-01377502

\section{HAL Id: hal-01377502 \\ https://hal.inria.fr/hal-01377502}

Submitted on 7 Oct 2016

HAL is a multi-disciplinary open access archive for the deposit and dissemination of scientific research documents, whether they are published or not. The documents may come from teaching and research institutions in France or abroad, or from public or private research centers.
L'archive ouverte pluridisciplinaire HAL, est destinée au dépôt et à la diffusion de documents scientifiques de niveau recherche, publiés ou non, émanant des établissements d'enseignement et de recherche français ou étrangers, des laboratoires publics ou privés. 


\title{
Business collaboration - an approach towards end-to- end ICT solutions for virtual factory
}

\author{
Ahm Shamsuzzoha ${ }^{1,2}$ and Petri Helo² \\ ${ }^{1}$ Department of Mechanical and Industrial Engineering, Sultan Qaboos University, Muscat, \\ Sultanate of Oman \\ ahsh@squ.edu.om \\ ${ }^{2}$ Department of Production, University of Vaasa, Vaasa, Finland \\ phelo@uva.fi
}

\begin{abstract}
Business collaboration attracts substantial attention within manufacturing communities globally. Companies are collaborating with each other in order to achieve open innovation and for gaining business benefits. This specific research proposes a new business environment known as virtual factory, where similar type of companies form and execute business ecosystem. Such changed business environment demands for an end-to-end communication framework in order to obtaining status update between each other business processes. This research initiates an approach to the formation and execution of a virtual factory business environment that offers one of the important concepts and foundations central to the realization of future manufacturing environment. The virtual factory that is supported by the end-to-end integration of ICT technologies ensures a plug-and-play business process management functionality. In addition to, this research carried out an effort to look into the current researches on virtual collaborations, their inherent requirements and presented a communication framework between collaborative partners through ICT-enabled infrastructure. A case example is highlighted within the scope of this research with the objective to demonstrate and validate the presented communication framework that is to be implemented to monitor and manage virtual factory business processes successfully.
\end{abstract}

Keywords: Virtual factory, end-to-end ICT solutions, business collaboration, process monitoring, SMEs

\section{Introduction}

Reduced investment capability of companies due to economic crisis, highly dynamic markets, intense competition and other external factors influences manufacturing companies to react quickly and the adoption of changes faster than before. Today's customers expect personalized products or services, which often make difficult for individual company to satisfy. To react such challenge, companies find other companies and integrate with them to work in collaborative enterprise networks [1]. In order to create such networks, companies not only the capability to 
identify, model and expose their core competences, but the capability to execute their business processes in an agile, short-time and often non-hierarchical business environments [2].

Due to global economic crisis, the manufacturing domain looks forward to achieve business benefits mostly by exploiting the latest advancements in ICT that supports a more productive, cost efficient and sustainable future. There exists distributed and flexible manufacturing domain in recent days, however there are lacking more responsive and agile manufacturing configurations to achieve added business potential [3]. In such business environment, dynamic manufacturing networks in the form of virtual factory stands out as a cutting-edge solution that enables manufacturing companies to drive into the new global economy. This concept is expedited through the ADVENTURE plug-and-play virtual factory business environment [4].

The concept of virtual factory emerge from the idea of formation and execution of business collaboration with the help of end-to-end ICT solutions. This business environment effectively support to highly customized and service-enhanced products along its life cycle. It promotes co-creation and co-innovation, involving the manufacturers, customers and local suppliers. To develop supporting tools and governance models for virtual business environment, it is necessary to first identify representative business scenarios that enable individual requirements to the collaboration. In this context, a set of relevant business scenarios for virtual business environment are derived from the requirements of the manufacturing domain are identified and discussed.

The rest of the paper is organized as follows: Section 2 represents the theoretical framework that outlines relevant information associated with virtual collaboration, while Section 3 defines virtual factory design requirements. Section 4 highlights the business framework for virtual factory in the form of brief explanation of its life cycle and associated sub-processes. An application of ADVENTURE virtual factory: endto-end integration of ICT solutions is presented in Section 5, whereas, the paper is concluded with discussions and future works in Section 6.

\section{Theoretical framework}

The formation of business collaboration is the natural evolution of typical supply chains that aim to respond to global business challenges [5]. Business collaboration in the form of virtual factory coined to express the establishment of dynamic alliances among manufacturing companies in order to gaining mutual benefits. The virtual factory constitute a demand-driven formation of enterprises for a certain purpose [6]. To be successful in such business environment, the interconnection and effective communication among the various systems of every participating enterprise is considered a precondition. This communication extends to shop floor of partner companies and is not limited to only systems level (e.g. ERP systems). The general objective behind forming such networks is to reduce both costs and time to market, while increasing flexibility, gaining access to new markets and resources, and utilizing collective intelligence on methodologies and procedures [7]. 
The implementation of ICT and particularly Internet technologies developments led to higher focus on virtual knowledge management and high value added activities when they comes to design collaborative business. These changes in the organizational structures and business models need collaboration among multiple stakeholders, where an organization shift from product-oriented enterprise to customer-oriented enterprise, a shift centralized system to a 'community or ecosystem oriented' system [8]. The developments in ICT sector and the emerging globalization of the economy, business collaboration or networking is becoming increasingly important for innovation and growth. In reality, easy interconnectivity between partner organizations is nowadays a pre-requisite in achieving competitive advantage.

Most of the global companies need to take initiatives to recover from lost opportunities during the last years. The manufacturing sector still plays a major role in the global economy and is seen as a vital sector for the successful future. To claim regular success in both private and public sectors, ICT has been identified as a key driver with a high potential to enhance manufacturing industry in a sustainable way [9]. The developments of ICT framework tend to consider business services as some form of 'black boxes' that enables companies to perform some actions, being more focused on data, control flow, and interoperability of collaborative processes. From a business aspect, such services offers benefit to the product that is delivered to a customer with higher satisfaction. Successful partners work together with other partners through ICT enablers who offer complimentary expertise such as assets, processes capabilities and capacities [10].

From the literature review, it is revealed that there are several dimensions within business collaboration as defined by many researchers [13, 14, 15]. Some of the major dimensions with their associated elements and benefits are illustrated in Table 1. From Table 1, it is noticed that major dimensions in business collaboration are information exchange, process coordination and monitoring, workflow management, governance model and production planning and scheduling.

Table 1. Various dimensions of virtual collaborations and their associated benefits.

\begin{tabular}{|c|c|c|}
\hline Dimensions & Elements & Advantages \\
\hline $\begin{array}{l}\text { Real-time } \\
\text { information } \\
\text { exchange among } \\
\text { partners }\end{array}$ & $\begin{array}{l}\text { - Ensure on time information } \\
\text { - Information visibility } \\
\text { - Access right for information } \\
\text { - Transparency of information }\end{array}$ & $\begin{array}{l}\text { - Reduce information gap } \\
\text { between partners } \\
\text { - Faster problem detection } \\
\text { - Improve trust between } \\
\text { partners } \\
\text { - Quick response rate }\end{array}$ \\
\hline $\begin{array}{l}\text { Business process } \\
\text { coordination and } \\
\text { monitoring }\end{array}$ & $\begin{array}{l}\text { - Collaborative process design and } \\
\text { development } \\
\text { - Infrastructure for process } \\
\text { coordination } \\
\text { - Process monitoring framework } \\
\text { - Storage of monitored data } \\
\end{array}$ & $\begin{array}{l}\text { - Optimize process } \\
\text { performance } \\
\text { - Minimize process uncertainty } \\
\text { - Improve collaborative service } \\
\text { level } \\
\text { - Reduce process related cost }\end{array}$ \\
\hline $\begin{array}{l}\text { Workflow } \\
\text { coordination and } \\
\text { management }\end{array}$ & $\begin{array}{l}\text { - Business workflow design and } \\
\text { management } \\
\text { - Integrate planning and } \\
\text { coordination system } \\
\end{array}$ & $\begin{array}{l}\text { - Enhance workflow efficiency } \\
\text { and accuracy } \\
\text { - Faster time-to-market } \\
\text { - Improve workflow } \\
\end{array}$ \\
\hline
\end{tabular}




\begin{tabular}{|c|c|c|}
\hline & $\begin{array}{l}\text { - Adaptation of appropriate } \\
\text { planning }\end{array}$ & $\begin{array}{l}\text { uncertainty } \\
\text { - Expand service } \\
\end{array}$ \\
\hline $\begin{array}{l}\text { New governance } \\
\text { model }\end{array}$ & $\begin{array}{l}\text { - Secure effective partnerships } \\
\text { governance } \\
\text { - Integrate automated business } \\
\text { processes } \\
\text { - Building and sustaining } \\
\text { legitimacy of the partnership }\end{array}$ & $\begin{array}{l}\text { - Improve accountability of } \\
\text { partnerships } \\
\text { - Ensure partner alignment and } \\
\text { power } \\
\text { - Better resource utilization } \\
\text { - Improve market share }\end{array}$ \\
\hline New methodology & $\begin{array}{l}\text { Plan for developing new business } \\
\text { models } \\
\text { - Understand on open } \\
\text { collaboration models } \\
\text { - Collective intelligence and crowd } \\
\text { sourcing models }\end{array}$ & $\begin{array}{l}\text { - } \text { Better business collaboration } \\
\text { - Effective use of partners } \\
\text { competencies and resources } \\
\text { - Forecast business success and } \\
\text { profitability } \\
\text { - Adapt expanded resource } \\
\text { pool }\end{array}$ \\
\hline $\begin{array}{l}\text { Synchronized } \\
\text { production } \\
\text { planning and } \\
\text { scheduling }\end{array}$ & $\begin{array}{l}\text { - Create efficient collaborative } \\
\text { material plan } \\
\text { - Synchronize the flow of } \\
\text { resources for multistage } \\
\text { production needs among partners } \\
\text { - Develop constraint-based } \\
\text { production schedules }\end{array}$ & $\begin{array}{l}\text { - Optimize process capacity } \\
\text { and utilization } \\
\text { - Reduce finished goods and } \\
\text { work-in-process inventory } \\
\text { - Minimize resource wastage } \\
\text { - Increase throughput }\end{array}$ \\
\hline
\end{tabular}

\section{Virtual factory design requirements: business, strategic and functional}

The requirements within virtual collaboration whether it is business, strategic or functional collaborative needs to assess them critically before moving forward to establish such network. It is therefore highly recommended to ensure state-of-the-art requirements collection and analyze them to get the optimum ones. Initially, in case of virtual factory environment, Broker Company needs to collect the requirements and shares with the potential partners in the proposed collaborative network. Such requirements are collected following three steps as highlighted in Figure 1.

From Figure 1, it is seen that there are three steps in the requirements collection process within virtual factory. Step 1 is designated as business requirements, while step 2 and 3 are strategic and functional requirements respectively.

There are several requirements within business requirements as presented in step 1 in Figure 1, however, major requirements are highlighted within this research scope. Market research and analysis is one of the important business requirements, which starts before initiating any forms of collaboration. During market research, possible business opportunities are identified based on customers' preferences and target market segment.is calculated eventually. . After finalizing the target market segment by the broker company of the defined collaborative business network, the next available business requirement is to look for potential partners and select them based on the their expertise, knowledge, experiences and product portfolios. The collaboration is formed after making an agreement between collaborative partners. 

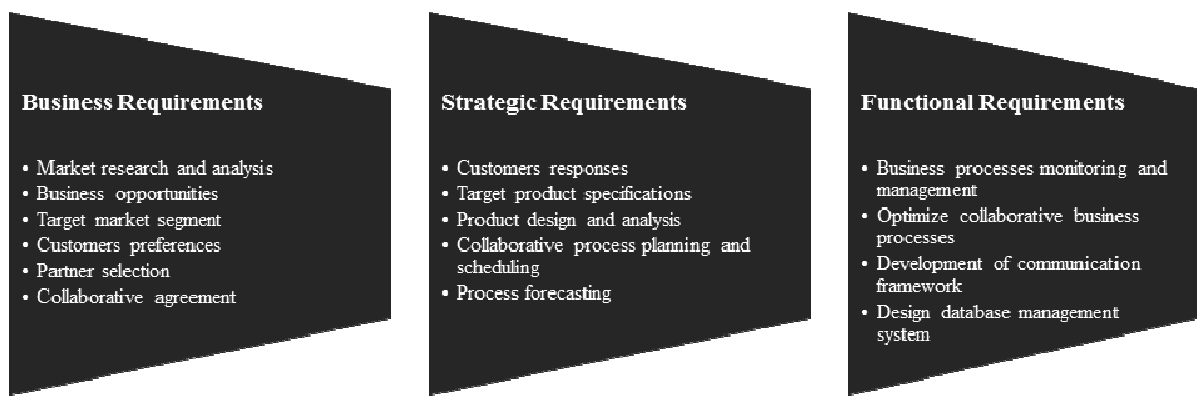

Fig. 1. Synoptic view of the virtual factory designed requirements

The second step of virtual factory designed requirements are strategic requirements, which are highly dependent on the previous business requirements. At this step, customers' responses as received from step 1 are analyzed and target product specifications are finalized. Based on the product specifications, essential product design and analysis are done. In order to develop the target product, required collaborative process planning and scheduling are performed. In addition to collaborative process planning, process forecasting is also considered as strategic requirement in order to design the business processes efficiently

The final step of virtual factory requirements are functional requirements, which are initiated based on strategic requirements. Within such requirements, business processes monitoring and, management is considered an important requirement. In functional requirements, partners also need to optimize their collaborative business processes. In order to execute a successful business collaboration in the form of virtual factory, partners need to design and develop a communication framework or channel with the objective to exchange information between partners that consequently support to track the process status. The final requirement is to design a database management system in order to store the process related data or information of the virtual factory.

\section{Business framework for virtual factory environment}

The business framework for virtual factory environment contains four levels namely, initiate, plug, play and dissolve as displayed in Figure 2. From Figure 1, it is seen that each of the step is consists of several sub-processes as needed to formation and execution of virtual factory successfully.

In the first step 'Initiate', Broker Company that initiates virtual collaboration in the form of virtual factory identifies new business opportunity after rigorous market survey. From this market survey major customers preferences are screened out before proceed towards collaborative network. The formation of collaboration initiates after defining partners selection criterions based upon potential partners are looked for. At this step, necessary governance model is initiated in addition to develop network's 
methodology. In order to measure the overall performance of the virtual collaboration several key performance indicators are also finalized at this phase.

In the plug phase of the virtual factory environment, partner's selection process is finalized and collaboration is started in order to achieve the identified business opportunity. All partners signed an agreement to share each other resources and expertise and maintain confidential information within the forum. The partners share design information of the proposed product after signing the agreement. At this step, production plan and operational routing and scheduling are initiated after finalized the product specifications. In this plug phase, a communication channel is established between the partners to exchange valuable information and to update collaborative processes statuses. The network governance model as initiated previous step also finalized at this phase.

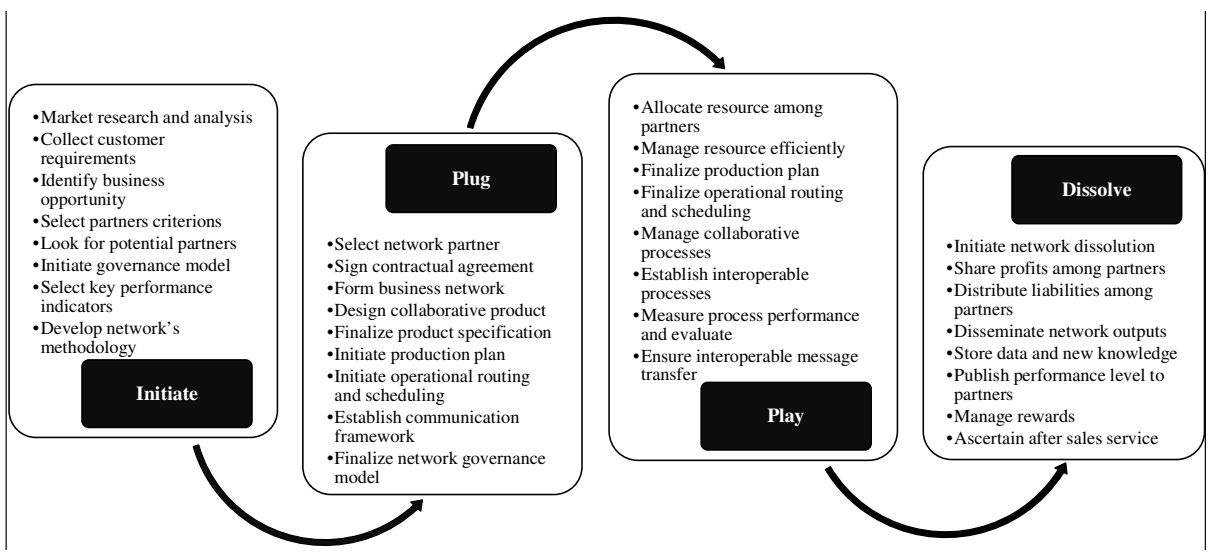

Fig. 2. Synoptic view of business framework for virtual factory environment

After selecting the potential partners, virtual factory's broker company allocate and share costly resources among partner companies, which are also managed efficiently among them. The required production plan and operational routing and scheduling are finalized at this phase. In the plug phase of the virtual factory environment, different collaborative processes are managed and to measure the processes performances for evaluation purpose. All the partners' processes are made interoperable in order to processes updates and establish smooth message transfer between each other.

Final step of the virtual factory environment concerns with dissolution of the entire business collaboration, which was formed temporarily based on the identified business opportunity. At this step, profits and liabilities of the virtual factory are shared among partners and disseminate the network's outcomes. New knowledge and data as achieved from this collaborative environment are stored in database system for future use. Overall performance of the individual partners are published within the network for further improvements. In case of better performance, partners are awarded as a recognition. Critical after sales service of the sold products is also ascertained at this phase, which is a part of customer service and satisfaction. 


\section{ADVENTURE virtual factory: an example of end-to-end integration of ICT solutions}

This section highlights an end-to-end integration of ICT solutions for virtual factory designed and developed under ADVENTURE project environment. The ADVENTURE is a project funded by European Union (EU), where the aims were to ensure virtual business collaborations among companies, mainly among small and medium size enterprises (SMEs) in EU [4]. The virtual factory needs several systems to manage effectively such as workflow management systems, project management systems, document management systems and collaboration management systems. In order to achieve such needs, virtual factory broker makes use virtual factory platform. Figure 3 displays an example of a process model within a virtual factory platform, where different sub-processes of a product design and delivery phases are illustrated.

From the process model as displayed in Figure 3, it is noticed that when a partner within virtual factory receives an order for very new equipment to be designed from scratch from a client, the ADVENTURE Process designer is used to model the entire manufacturing process.

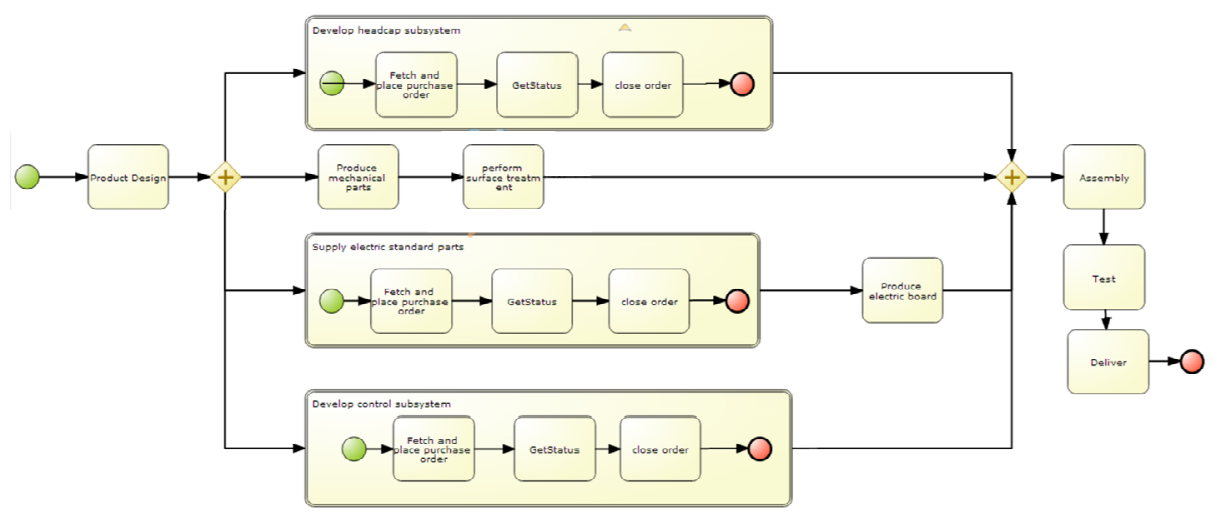

Fig. 3. Virtual factory process model designed in ADVENTURE platform

Implementing the Process Designer component and the integration with the Partner management system, the partner company is able to search and select for suitable partners, filtering them through non-functional requirements (e.g., $\mathrm{CO}_{2}$ emissions, lead-time, cost, location, etc...) and assign them to each external order. When the essential processes are defined, the partner company can use the Simulation and Optimization components, as part of the ADVENTURE platform to achieve the best result for this concrete process. After optimizing the process, it is necessary to execute it, which is done by the ADVENTURE Smart Process Engine component that controls the workflow and invokes services on the partner company's internal legacy systems (Figure 4) as well as on active virtual factory members' legacy systems. For those partners who are not technically integrated in the portal, web user interfaces will be available or its interaction with the system. 


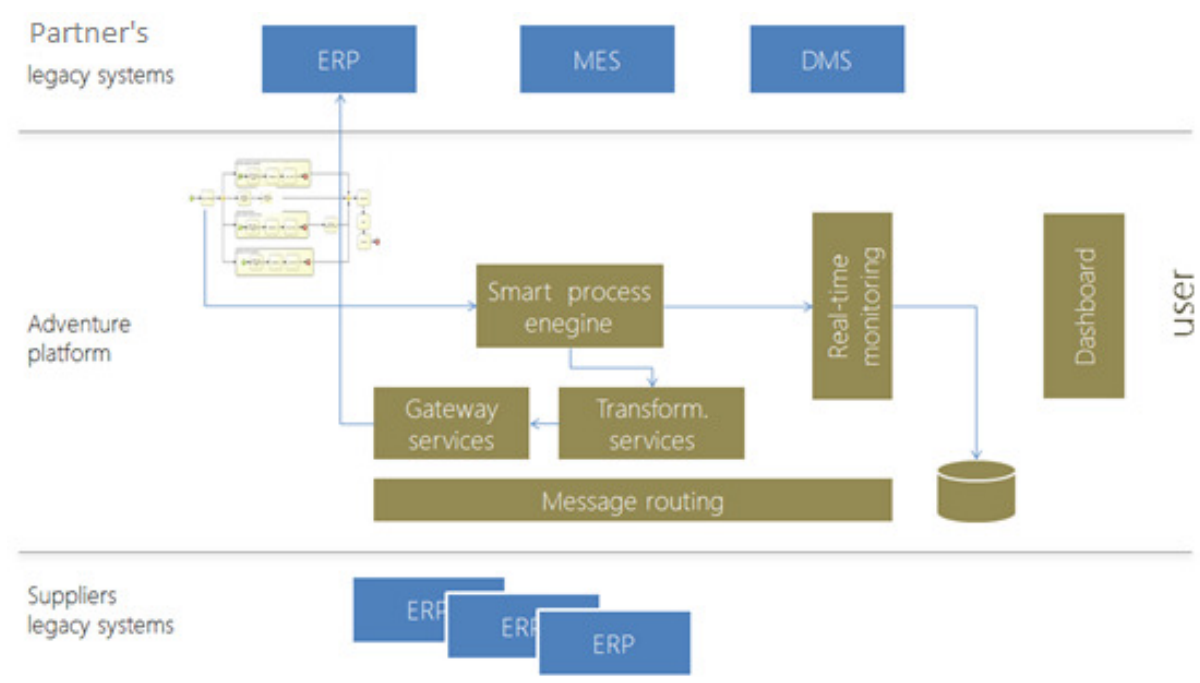

Fig. 4. Placing an order in virtual factory partner's ERP system

In order to place an order in virtual factory partner's legacy system, the Smart Process Engine imports the model from Process Designer and invokes the respective gateway service assigned to the internal task (see Figure 4). The procedure to place an order to a supplier's legacy system is similar to Figure 4. From Figure 4, it is noticed that ADVENTURE platform make the interfacing between partner's legacy systems and supplier's legacy system in placing an order.

In case of placing an order in partner's ERP system, it is noticed from Figure 4 that partner's ERP system received an order through ADVENTURE platform, where the order is processed through smart process engine, transform services and gateway services. This order process is also monitored through real-time monitoring module before saved in the ADVENTURE Cloud data storage. Eventually, the user can visualize the order status through dashboard module as depicted in Figure 4.

\section{Discussions and conclusion}

Comparatively easy access to global resources and capabilities enables manufacturing companies to select most suitable partner to form a temporary business network with the objective to meet complex customer demand. Such interorganizational relations among business partners offer increased competitive power, which is often not possible for an individual company to achieve. Such legally bonded collaborative forum is often named as virtual organization [11], virtual factory [6], business community [12], etc. In such business network, each of the partner's core competencies and resources are used to produce complex, capital-intensive products that is carried out along process chains, composed of the contributions of different partner companies [1]. 
The effort of business collaboration becomes known after identifying a business opportunity, where the broker company invites and selected partner companies. Such collaboration implements collaborative processes where all partners have to create a common result. These processes can effectively be managed through end-to-end integration with ICT solutions. The impact of such ICT solutions enable virtual collaborations to react dynamically with partner companies through providing realtime communication framework. The real-time communication framework provides necessary support to monitor and manage the collaboration.

This research work highlights elaborately to an end-to-end ICT framework that is to be applicable for virtual factory environment. This framework provides the detailed phases of the VF life cycle along with associated sub-processes. These sub-processes and their individual functionalities are explained for further use. The presented ICT framework is implemented in a case business network, where the broker company uses the framework to manage both of its own legacy systems as well as suppliers' one to place an order. With the scope of this framework, a complete order placement process from partner's ERP system to supplier's ERP system is explained. This complete order placement process can also be monitored and managed through such framework.

Future research can be investigated to extensively study the potential limitations and risks of the business collaboration. In addition to, advanced ICT framework can also be designed and developed to support agile and resilient virtual collaborations.

\section{Acknowledgements}

The authors would like to acknowledge the co-funding of the European Commission in NMP priority of the Seventh RTD Framework Programme (2007-13) for the ADVENTURE project (ADaptive Virtual ENterprise ManufacTURing Environment), Ref. 285220. The authors also acknowledge the valuable collaboration provided by the project team during the research work.

\section{References}

1. Sitek, P. Seifert, M. and Thoben, K-D.: Towards an inter-organisational perspective for managing quality in virtual organisations. International Journal of Quality \& Reliability Management, vol. 27, no. 2, pp. 231 - 246, (2010)

2. Karlsson, C.:The development of industrial networks: challenges to operations management in an extraprise, International Journal of Operations \& Production Management, vol. 23, no. 1, pp. 44-61 (2003)

3. Markaki, O., Panopoulos, D., Kokkinakos, P., Koussouris, S. and Askounis, D.: Towards Adopting Dynamic Manufacturing Networks for Future Manufacturing: Benefits and Risks of the IMAGINE DMN End-to-End Management Methodology. In: Enabling Technologies: Infrastructure for Collaborative Enterprises (WETICE), 2013 IEEE 22nd International Workshop on, pp. 305-310, IEEE Press, Hammamet (2013)

4. ADVENTURE:, Adaptive Virtual Enterprise Manufacturing Environment, European RTD project, Grant agreement no: 285220, Duration 01.9.2011-31.08.2014 (2014) 
5. Camarinha-Matos, L.M., Afsarmanesh, H., Ollus, M.: ECOLEAD and CNO base concepts. In: Camarinha-Matos, L.M., Afsarmanesh, H., Ollus, M. (eds.) Methods and Tools for Collaborative Networked Organizations, vol. VIII, pp. 3-32. Springer (2008)

6. Shamsuzzoha, A. and Helo, P.: Virtual Business Process Management Within Collaborative Manufacturing Network: An Implementation Case. International Journal of Networking and Virtual Organisations, vol. 14, no. 4, pp. 319-339, (2014)

7. Kokkinakos, P., Markaki, O., Panopoulos, D., Koussouris, S. and Askounis, D.: Dynamic Manufacturing Networks Monitoring and Governance. In: C. Emmanouilidis, M. Taisch, D. Kiritsis (Eds.): APMS 2012, Part II, IFIP AICT 398, pp. 446-453, (2013)

8. Camarinha-Matos, L.M., Macedo, P., Ferrada, F. and Olivera, A.I.: Collaborative Business Scenarios in a Service-Enhanced Products Ecosystem. In: Camarinha-Matos, Xu, L. and Afsarmanesh, H. (Eds.): PRO-VE 2012, IFIP AICT 380, pp. 13-25, (2012)

9. Taisch, M., Stahl, B. and Tavola, G.: ICT in Manufacturing: Trends and Challenges for 2020 - An European View. In: 10th IEEE International Conference on Industrial Informatics (INDIN), IEEE Press, Beijing, pp. 941-946, (2012)

10. Walters, D.: Competition, Collaboration, and Creating Value in the Value Chain. In: Modelling Value, Contributions To Management Science: Selected Papers of the 1st International Conference on Value Chain Management, H. Jodlbauer, J. Olhager, and R. J. Schonberger, Eds., pp. 3-36, University of Applied Sciences in Upper Austria, School of Management, Steyr, Austria, 2012.

11. Sydow, J.: Strategische Netzwerke: Evolution und Organisation, Gabler Verlag, Wiesbaden (in German) (1993)

12. Shamsuzzoha, A., Kankaanpää, T., Carneiro, L., Almeida, R., Chiodi, A. and Fornasiero, R.: Dynamic and Collaborative Business Networks in the Fashion Industry. International Journal of Computer Integrated Manufacturing, vol. 26, no. 1-2, pp. 125-139 (2013)

13. Dekkers, R. and Kuhnle, H.: Appraising Interdisciplinary Contributions to Theory for Collaborative (Manufacturing) Networks: Still a Long Way to Go? Journal of Manufacturing Technology Management, vol. 23, no. 8, pp. 1090-1128 (2012)

14.Agranoff, R.: Inside Collaborative Networks: Ten Lessons for Public Managers", Public Administration Review, vol. 66, no. 1, pp. 56-65 (2006)15.Eschenbächer, J., Seifert, M. and Thoben, K.-D.: Managing Distributed Innovation Processes in Virtual Organizations by Applying the Collaborative Network Relationship Analysis, in Camarinha-Matos, L.M., Paraskakis, I. and Afsarmanesh, H. (Eds), Leveraging Knowledge for Innovation in Collaborative Networks, Springer, Berlin, pp. 13-22 (2009) 